\title{
CONSTITUTIONAL IMPLICATIONS OF EU MEMBERSHIP: AN OVERVIEW OF CONSTITUTIONAL ISSUES IN THE NEGOTIATING PROCESS - THE CROATIAN PERSPECTIVE ${ }^{1}$
}

\begin{abstract}
Irena Andrassy*
Summary: This article gives an overview of the constitutional issues arising from Croatia's EU accession negotiations. Corresponding to the current status of negotiations, a provisional overview is made, consisting of the constitutional issues that are either already on the negotiating agenda or anticipated on the basis of the existing, internal legal analyses and/or the experiences of candidate countries from previous enlargements. They are divided into three groups: 1) constitutional issues which have arisen during the screening process and in subsequent talks and negotiations with the EU on individual negotiating chapters; 2) constitutional issues which have not been directly raised in negotiations with the EU, but which Croatia needs to consider in the context of the overall preparations for EU accession; 3) the possible further constitutional implications of EU membership following the entry into force of the latest EU treaty reform.

The article looks at how Croatia and the EU approach these constitutional issues in the context of accession negotiations, especially having in mind the new procedural mechanisms (ie benchmarks) introduced by the EU into the process of negotiations. Different approaches are also determined by the type of constitutional issues: the sector-specific issues related to legislative alignment in certain areas of the acquis, which will be addressed in the course of negotiations on individual chapters, are distinguished in principle from the general constitutional issues related to finding the 'right' constitutional legal basis and formula for Croatia's accession to and effective functioning in the EU (where Croatia has to decide on its own on the need for constitutional adjustments and the manner of making them).

In comparison with the previous EU enlargement round, the analysis shows that there are no significant differences in Croatia's accession negotiations with respect to the areas in which constitutional issues
\end{abstract}

\footnotetext{
1 This article was originally prepared for and presented at the Conference 'Constitutional Implications of EU Membership', held in Zagreb on 20 April 2007. Due to further developments in accession negotiations between the EU and Croatia, as well as in the EU treaty reform over the past year, some segments of the text have been updated and revised accordingly.

" Irena Andrassy, MSc, Legal Adviser of the Chief Negotiator of the Republic of Croatia for Accession to the EU. The comments and views expressed are personal.
} 
have been identified. Croatia will be able to use the experiences of the 'new' EU Member States, although there are no standard or best solutions for adjusting the constitutional legal framework for EU accession. The final list of all constitutional issues that Croatia will (have to) address before accession to the EU will directly depend on the results of negotiations as well as on wider legal and political deliberations that are expected to take place in Croatia in the coming period.

\section{Introduction}

For a candidate country, preparations for EU membership entail the comprehensive adjustment of its whole legal, economic and administrative system. In order to fulfil a plethora of political, economic, legal and administrative criteria and conditions, a candidate country has to go through a complex technical process of approximation of legislation and administrative capacity building, but also has to face substantial reforms and changes to its core state functions and competences. Since EU accession also implies a transfer of some constitutional powers to EU institutions, preparations for membership inevitably include certain constitutional preparations as well. All these constitutional and other necessary reforms will be tackled by Croatia in the course of accession negotiations.

In terms of substantive negotiations - if judged by the number of exchanged negotiating positions between Croatia and the EU and the number of negotiating chapters in which the two sides have entered into more substantive talks - Croatia is now in an advanced phase of accession negotiations. ${ }^{2}$ Still, a complete list of all constitutional issues that Croatia will face before (and after) accession to the EU will only be known at the very last stage of negotiations, in some aspects directly depending on further developments and the results of technical negotiations. Therefore, at this stage of the process a provisional overview of expected constitutional issues has been made, consisting of issues that are either already on the negotiating agenda or anticipated on the basis of the existing, internal legal analyses and/or the experiences of candidate countries from previous enlargements. For the purpose of this overview, all existing and potential constitutional issues and implications have been divided into three groups:

\footnotetext{
2 At the time of the Conference, Croatia was still in an early phase of negotiations, with 2 negotiating chapters (25 - Science and Research; 26 - Education and Culture) provisionally closed and 4 others opened for negotiations. In July 2008 the number of formally opened chapters was 21 , which is more than half of all negotiating chapters (three chapters are provisionally closed).
} 
I. Constitutional issues which have arisen during the screening process and in subsequent talks and negotiations with the EU on individual chapters;

II. Constitutional issues which have not been directly raised in negotiations with the EU, but which Croatia already needs to take into consideration at this stage of the accession process - eg general questions linked to EU accession, including the constitutional basis for accession;

III. Possible further constitutional implications of EU membership following the entry into force of the latest EU treaty reform.

\section{Constitutional issues which have arisen during the screening process and in subsequent talks and negotiations with the EU on individual chapters}

The overview of constitutional issues arising in individual chapters has primarily been made on the basis of the screening results presented in the Screening Reports of the European Commission. ${ }^{3}$

The so-called screening process, on the basis of which substantive negotiations between Croatia and the EU Member States are now being carried out, started in October 2005 and lasted for one year. It entailed a detailed analysis and assessment of the level of alignment of the Croatian legislation with the acquis communautaire, for the purpose of identifying questions that might occur during negotiations.

In comparison with the previous round of EU enlargement, this time around the screening exercise has been much more elaborated and thorough - not only because of the significant evolution of the acquis (now divided into 35 chapters, 33 of which are screened), but also due to the EU's stricter and more rigorous approach to accession negotiations. During screening, Croatia provided more than 20,000 pages of documents to the European Commission, explaining in detail Croatia's current legislative and institutional framework and assessing the areas in which changes would be needed for the full and effective implementation of the acquis in each individual negotiating chapter.

This new methodology resulted in more detailed Screening Reports of the Commission and consequently in more extensive lists of adjustments of the Croatian legal system that the Commission considers necessary for Croatia's accession to the EU. Among those, a number of constitutional issues have been identified as well. Since the Commission Screening Reports serve as the basis for the preparation of Croatia's, and ultimately the EU's, negotiating positions, these constitutional issues are expected to arise, or have already arisen, in the substantive phase of negotiations on individual chapters. They are presented in Table 1.

${ }_{3}$ See $<$ http://ec.europa.eu/enlargement/croatia/screening_reports_en.htm $>$. 


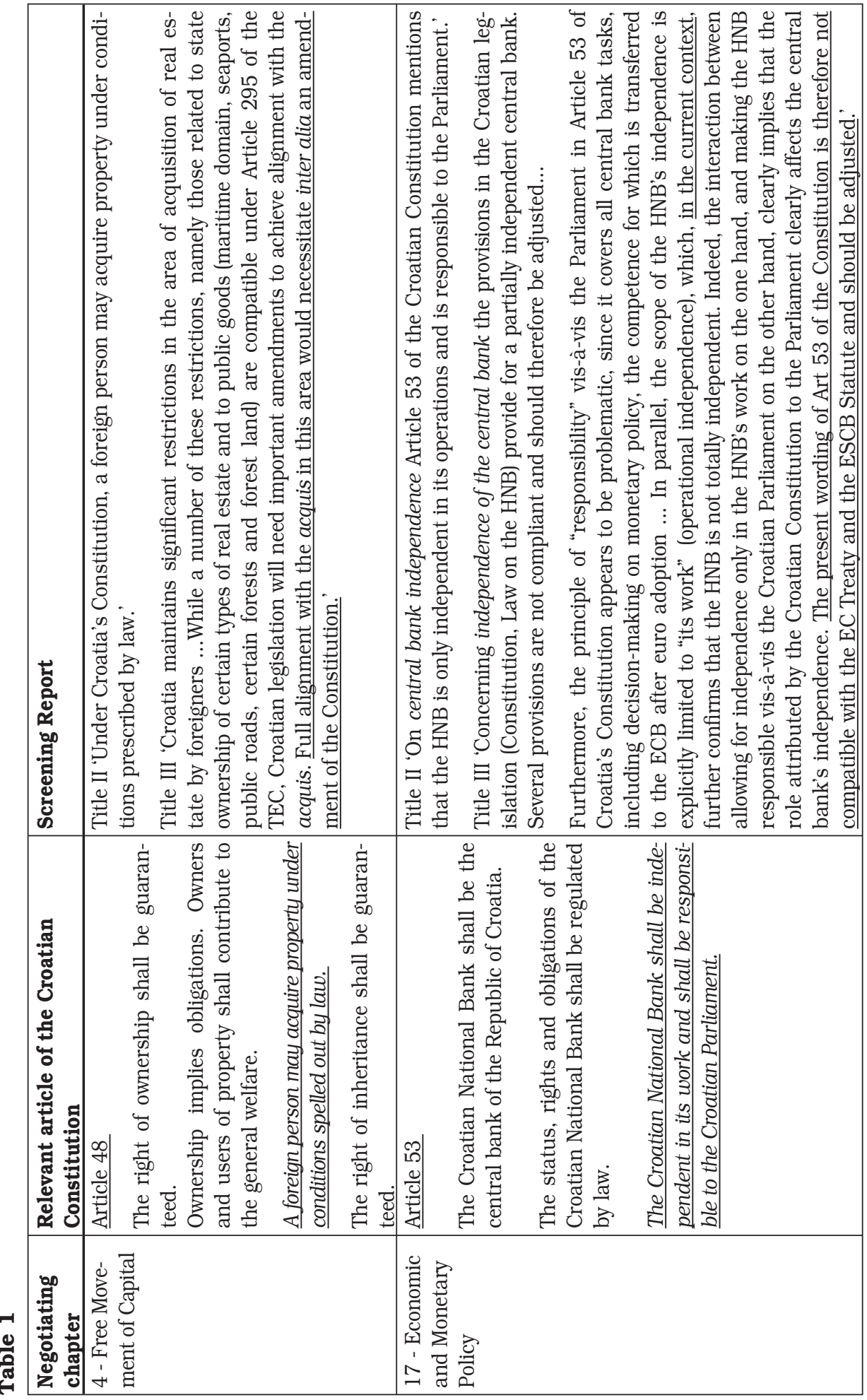




\begin{tabular}{|c|c|c|c|c|c|c|}
\hline & 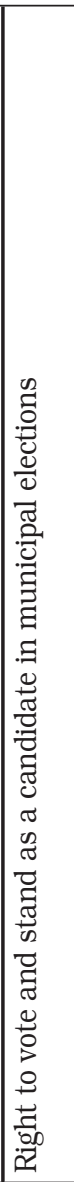 & \multicolumn{4}{|c|}{ 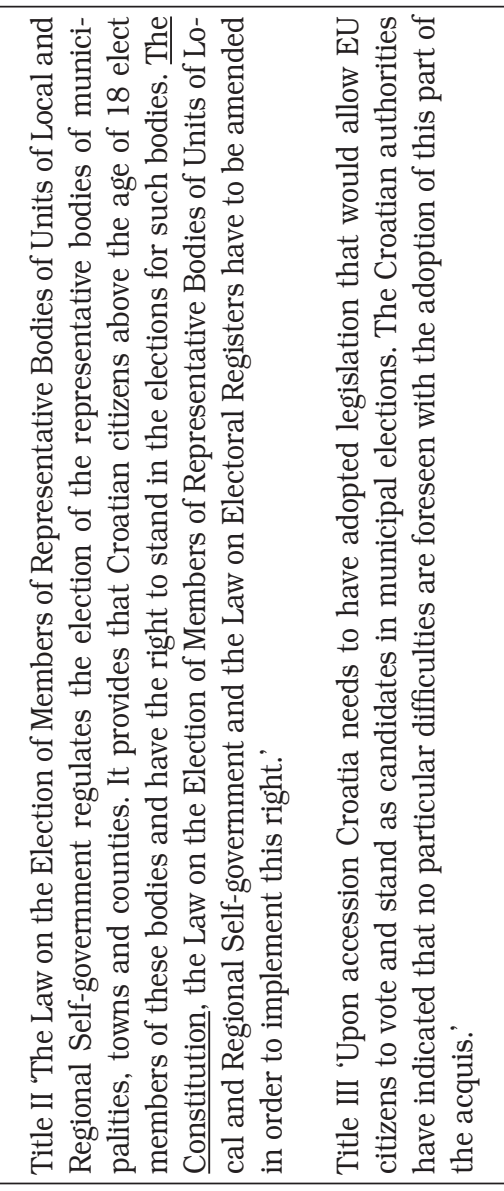 } & \\
\hline 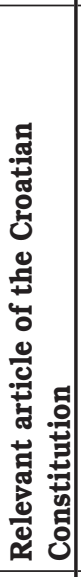 & 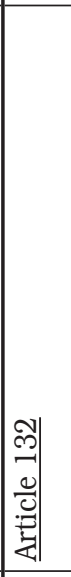 & 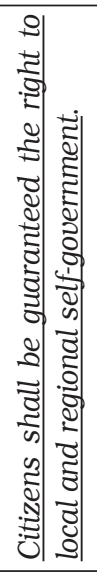 & 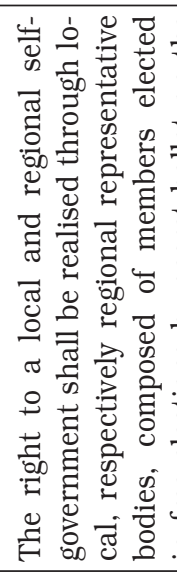 & 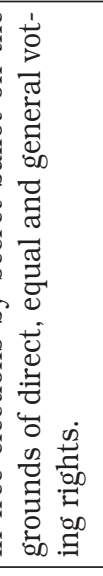 & $\begin{array}{l}\text { 워 } \\
\stackrel{0}{c} \\
\stackrel{2}{2}\end{array}$ & 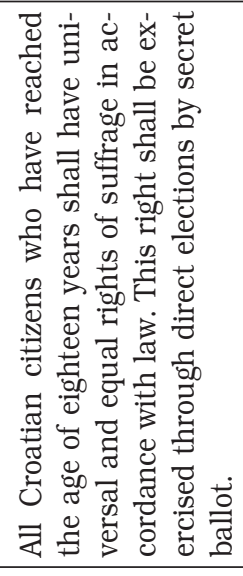 \\
\hline 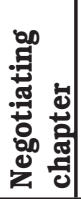 & & & & & & \\
\hline
\end{tabular}




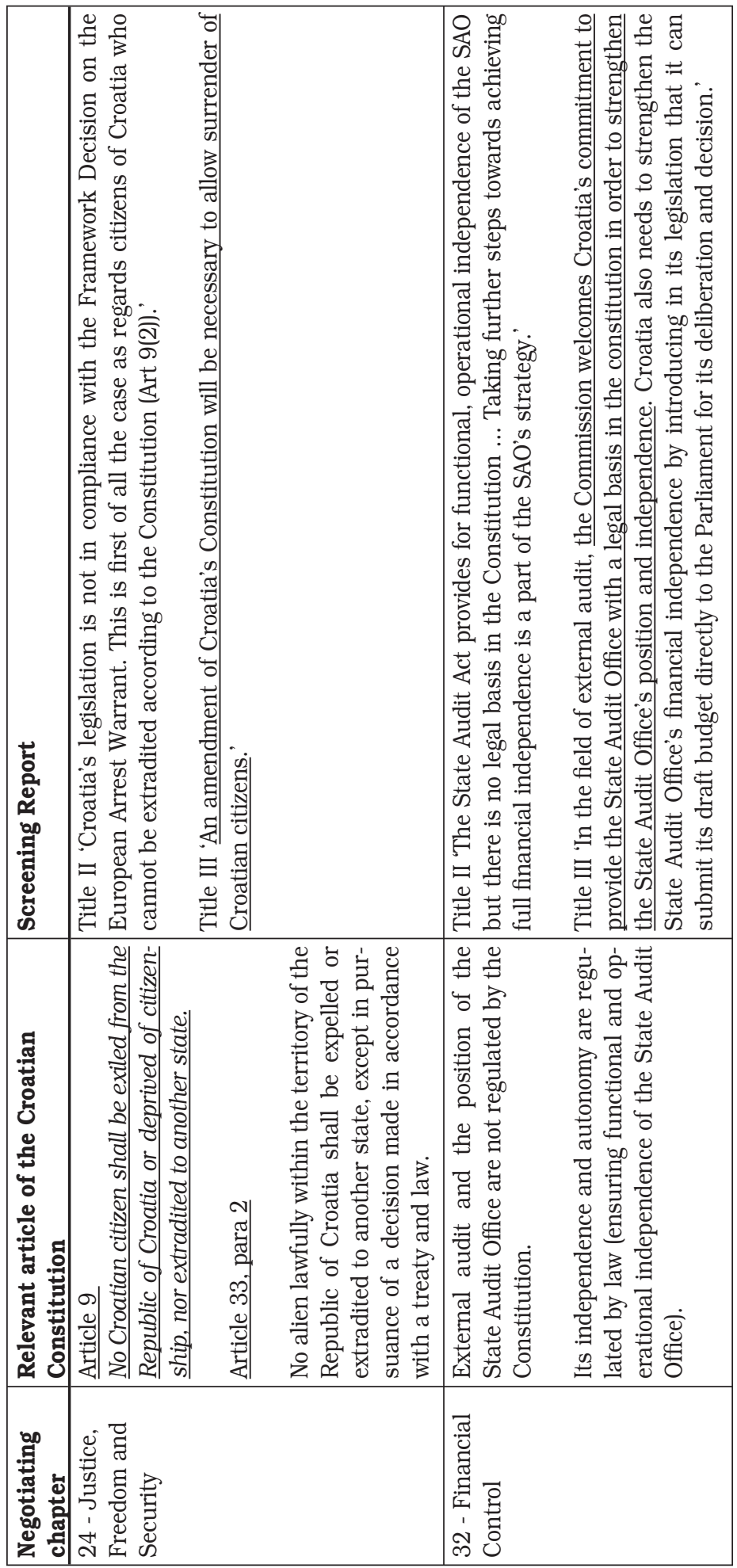


According to this overview, the list of potential constitutional issues does not seem to be too long. If compared with the candidate countries from the previous EU enlargement, there are no significant differences with respect to the areas in which constitutional issues arise in Croatia. There are a number of recurring issues - in Croatia's case understandably reflecting the features and specific qualities of the Croatian constitutional system. In terms of scope of potential constitutional changes, Croatia could figure somewhere in between the countries with minimal EU amendments and those with a medium package of EU constitutional amendments. ${ }^{4}$

The main characteristics of the outlined constitutional issues can be analysed according to several factors: the type of constitutional provision and its relation to the acquis, the nature of the acquis regulating a particular area, the main initiator of constitutional changes, and the type of possible constitutional amendments.

\section{The European Arrest Warrant (Chapter 24).}

The implementation of the Framework Decision on the European Arrest Warrant ${ }^{5}$ upon Croatia's accession to the EU will require the possibility to extradite (surrender) Croatian citizens from Croatia to another EU Member State. This is currently prohibited by the Croatian Constitution, which makes the relevant constitutional provision incompatible with the acquis. Since Croatia will have to transpose the Framework Decision provisions into its own legal system in order to apply them upon accession, it is reasonable to expect that the respective constitutional provision would have to be amended beforehand. Otherwise, the legal act transposing the Framework Decision, if fully aligned with the acquis, might be assessed as unconstitutional. ${ }^{6}$

This potential constitutional change is directly linked to the legislative alignment with specific provisions of the acquis, which a candidate country is obliged to make within a certain period before accession. Theoretically, if the national legislation, including the constitutional law (according to the ECJ's jurisprudence), remained contrary to the EU legislation, the acquis would take precedence in line with the principle of

\footnotetext{
4 Anneli Albi, EU Enlargement and the Constitutions of Central and Eastern Europe (Cambridge University Press, Cambridge 2005) 67-121.

5 2002/584/JHA: Council Framework Decision of 13 June 2002 on the European arrest warrant and the surrender procedures between Member States [2002] OJ L 190/1.

${ }^{6}$ Except if its entry into force could be linked to a constitutional amendment. Consequently, it is difficult to provide to the EU the envisaged date of full alignment with the acquis or the adoption of a certain implementing act which, if adopted before the constitutional change, would be contrary to the Constitution (eg an act transposing the provisions from the Framework Decision on the European Arrest Warrant).
} 
supremacy. But the situation is more complicated when the incompatible piece of legislation is the Constitution itself, because this could lead to internal debates on constitutional supremacy and the relationship between the EU's and national constitutional systems in general. ${ }^{7}$ So, in order to avoid long constitutional debates, as well as potential ECJ cases and challenges to the constitutionality of national laws and regulations, the more pragmatic approach would be to change the Constitution prior to EU accession. ${ }^{8}$

In this case, Croatia and the Commission/EU could agree on amendments to the Croatian Constitution to prevent any potential conflicts with the acquis. As to how this should be done, there are different models to follow - from countries which generally allow the extradition of their citizens, to those which allow it only for the purposes of implementing their international and/or EU obligations.

\section{The independence of the Croatian National Bank (CNB) (Chapter 17).}

Unlike the previous case, Croatia and the Commission/EU might not necessarily share the same views when it comes to the constitutional provision on the CNB and its compatibility with the acquis. Whereas the Commission expressed the opinion in its 2006 Screening Report that the wording of Article 53 of the Constitution, in the then existing legal context, was not compatible with the EC Treaty and the ESCB Statute, because it supposedly did not guarantee the central bank's full independence, one could argue that this very general article of the Constitution is not in direct conflict with the acquis and that its 'adequacy' should be subject to interpretation, including through the relevant law on the CNB. Namely, since according to the Constitution the status, rights and obligations of the CNB are regulated by law, it could be claimed that the constitutional provision is given its full meaning only if read together with the CNB Act, which defines in more detail the nature and scope of the operational, functional and personal independence of the CNB. Thus, it would not be necessary to amend the constitutional provision, but to fully align the CNB Act. In this way, the constitutional provision could be interpreted and assessed in the new legal context of the fully aligned CNB Act (which was adopted in June 2008) and the actual practice on the ground, which could remove all uncertainties and doubts that the CNB's full independence might be threatened by Parliament's influence. ${ }^{9}$

\footnotetext{
7 Unless this question is fully resolved by the explicit recognition of the supremacy of EU law over constitutional law, which is not (yet) the case in the Croatian Constitution.

8 Some new Member States left this issue unresolved, which resulted in constitutional conflicts, court cases and subsequent constitutional changes after accession to the EU.

9 This approach has been taken in some Member States (like Slovenia and Finland).
} 
Given the above, further talks and discussions between Croatia and the EU on this issue are being held under Chapter 17 - Economic and Monetary Policy (which was opened for negotiations in December 2006).

\section{The purchase of real estate by foreigners (Chapter 4).}

This issue is potentially very similar to the one explained under point 2 , because it is also related to legislative alignment with the acquis, while the 'pressure' to change the Constitution, and not only the relevant laws, comes from the Commission (not Croatia). Namely, in the Commission's opinion, full alignment with the acquis in this area would also necessitate an amendment of the Constitution, even though the constitutional provision is in principle permissive, ie allowing - and not prohibiting, as was the case in some previous candidate countries - foreigners to acquire real estate in Croatia.

Since the purchase of real estate by foreigners will certainly be one of the most sensitive issues in Croatia's accession negotiations, the resolution of this constitutional issue will directly depend on the negotiating positions of Croatia and the EU, and ultimately on the negotiation results (the present constitutional provision can, for example, cover possible transitional periods for certain types of real estate, such as agricultural land, and/or the permanently maintained restrictions in line with the acquis in relation to third countries). In other words, an unconditional constitutional provision would essentially not be legally feasible if negotiations with the EU resulted in a transitional period for the acquisition of a certain type of real estate, at least for the duration of that period. Hence, one could argue that there is enough room to interpret the current constitutional provision in line with the acquis, so it can remain unchanged, provided that all restrictions that are not compatible with the acquis, and are not accepted by the EU in negotiations, are removed from the relevant laws or are not applied to EU/EEA nationals.

\section{Independence of the State Audit Office (SAO) (Chapter 32).}

This constitutional issue is rather different from the previous ones because: a) it includes the request to provide the State Audit Office with a legal basis in the Constitution in order to strengthen the SAO's position and independence, ie to create a new constitutional provision in the area in which it currently does not exist; b) unlike the previous three cases, this question is not directly regulated by explicit rules within the acquis, thus constitutional amendment is not required for legislative alignment with the hard acquis, but is only advisable as an additional guarantee of institutional independence in line with some best EU practices and rec- 
ommendations; ${ }^{10} \mathrm{c}$ ) the 'pressure' for constitutional change comes from both Croatia and the Commission/EU. ${ }^{11}$

After the formal opening of negotiations on Chapter 32 (in June 2007), this issue has been a subject of bilateral consultations, since further strengthening and safeguarding of the State Audit Office's independence - through constitutional provisions and/or other appropriate legislative amendments - has been indicated by the EU as one of the requirements for the provisional closure of this chapter.

\section{EU citizens rights - the right to vote and stand as a candidate in municipal elections in Croatia (Chapter 23).}

The Constitution currently guarantees the right of suffrage and participation in local/regional self-government to Croatian citizens only, linking it primarily to the principle of nationality/citizenship. ${ }^{12}$ At the same time, one could argue that the existing constitutional provision does not prohibit the extension of this right to EU citizens, so it could be expanded (and applied from accession) through relevant laws to all EU citizens residing in Croatia, without necessarily involving a constitutional change. However, due to the wider context, ${ }^{13}$ Croatia may decide to amend the relevant constitutional provisions in the process to prevent any ambiguities in their interpretation or potential debates about the relationship between the provisions of the Constitution and the EC/EU Treaty.

As presented in Table 2, we can note that all five explained constitutional issues are marked by a different combination of factors. However, the main underlying factor, which might determine the actual need for constitutional change, is the legal necessity of that change to ensure the full alignment of Croatia's legislation with the acquis in a certain area.

\footnotetext{
10 The existing constitutional models and traditions of EU Member States are all quite different in that respect.

11 The initiative initially came from the SAO, but was also welcomed and supported by the Commission/EU; see the Screening Report on Chapter 32 and the Commission's 2006 Progress Report <http://ec.europa.eu/enlargement/croatia/key_documents_en.htm>.

12 The definition of 'citizens' referred to in Article 132 of the Constitution is actually provided in the Act on the Election of Members of Representative Bodies of Units of Local and Regional Self-government, which stipulates that Croatian citizens above the age of 18 elect members of the representative bodies of municipalities, towns and counties (in which they reside) and have the right to stand in the elections for such bodies. This right is based on direct, equal and general voting rights, which are guaranteed under Article 45 of the Constitution to Croatian citizens above the age of 18.

13 The combination of Articles 45 and 132 and some other provisions of the Constitution.
} 


\begin{tabular}{|c|c|c|c|c|c|}
\hline 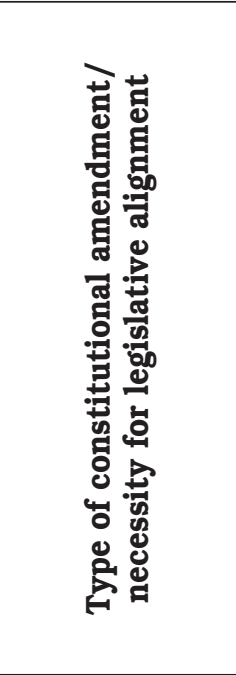 & 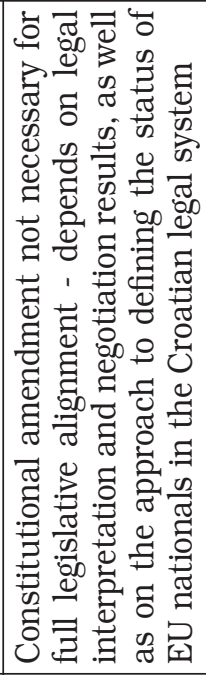 & 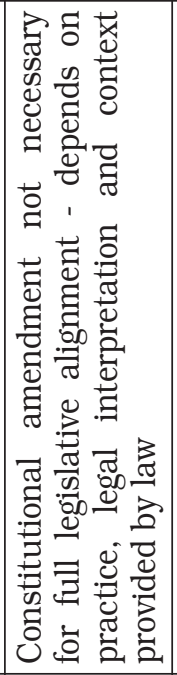 & 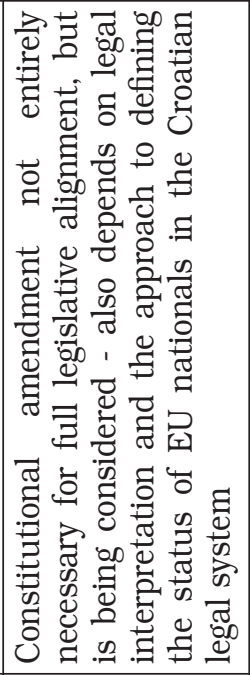 & 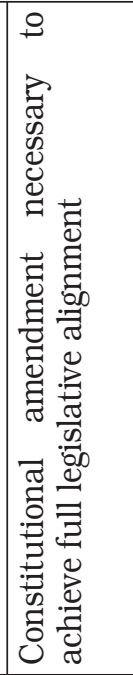 & 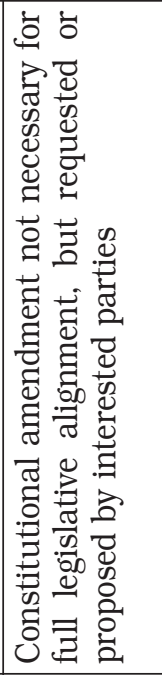 \\
\hline 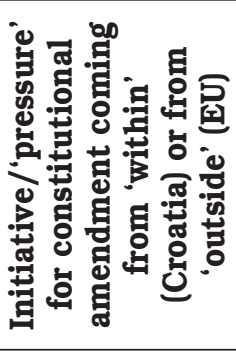 & |? & 只 & 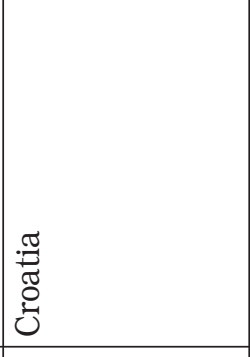 & 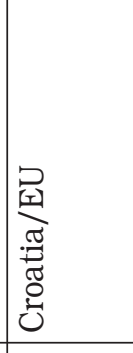 & 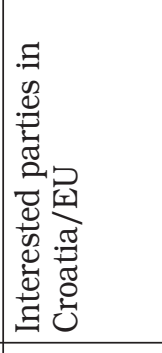 \\
\hline 葛 & 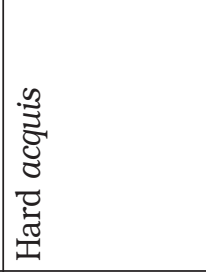 & 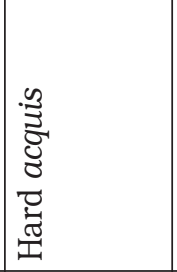 & 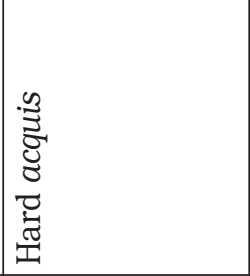 & 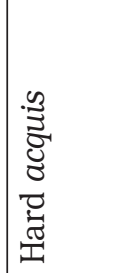 & 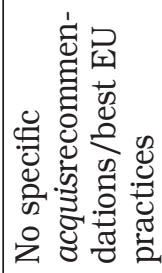 \\
\hline 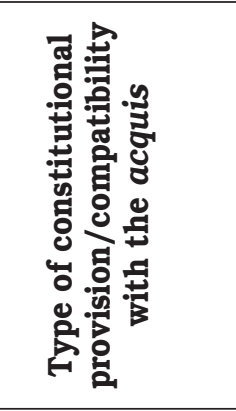 & 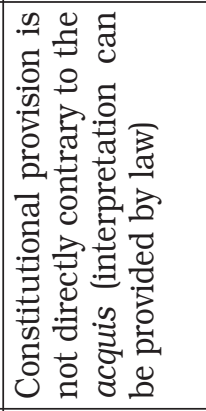 & 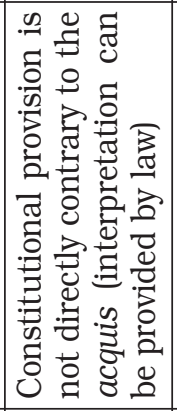 & 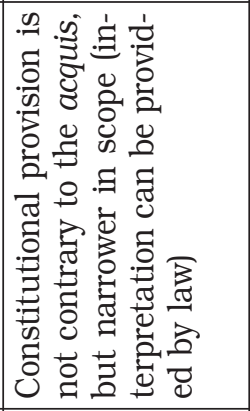 & 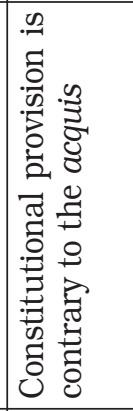 & 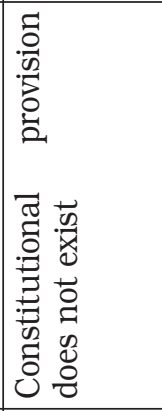 \\
\hline 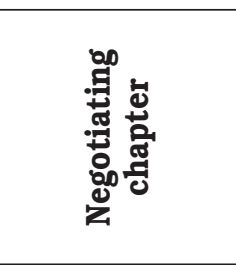 & 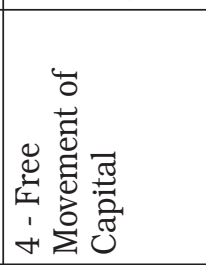 & 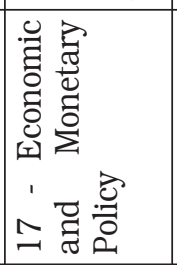 & 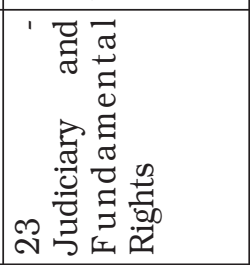 & 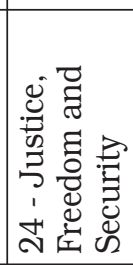 & 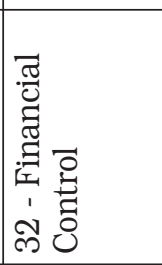 \\
\hline
\end{tabular}


Given the above analysis, it is clear that Croatia will have to embark on some constitutional changes in order to prepare for EU membership. However, in terms of negotiations, the actual treatment and approach to these constitutional issues might be different in each of the presented cases, also depending on whether or not they (will) occur in the EU's negotiating positions as explicit or implicit conditions for the provisional closure of individual chapters.

Against this background, the question is how a candidate country can approach the constitutional issues in the context of the accession negotiations.

The Constitution is a fundamental national legal act which determines the organisation of a state and its government, the state institutions and the division of their powers, as well as human and fundamental rights. It is a very specific legal and political document, and is the basis of the state's legal and political system. Hence, any discussion on potential changes brings to the fore very sensitive and complex legal questions, and, no less importantly, some very political questions as well. Given its fundamental nature, it is generally considered that the Constitution cannot be subjected to the 'ordinary' process of legislative alignment with the acquis or to too many and too frequent changes. It is difficult, not to mention legally highly controversial, to change the Constitution very often.

Based on this understanding, the preferred scenario would be for Croatia to gain an overall picture of all the necessary constitutional changes before embarking on them. The possibility to treat the constitutional amendments in a comprehensive manner has the advantage of not having to tackle such a sensitive issue on several occasions. Under ordinary circumstances, the first opportunity to have a full overview of all the required constitutional changes would be the finalisation of negotiations in all the negotiating chapters. However, the new mechanism of closing benchmarks might create situations in which Croatia would not be able even to provisionally close a negotiating chapter before a constitutional change takes place. Since this would bring more uncertainty into the negotiating process and potentially create the need for repeated constitutional changes, it would be preferable not to have the provisional closure of individual chapters conditioned by the adoption of constitutional amendments (ie not to have constitutional questions as part of the closing benchmarks). If really needed, ie in the case where constitutional change is related to legislative alignment with the hard acquis and/or the elimination of a potential constitutional conflict with the acquis, a compromise formula could be found in the obligation to carry out necessary constitutional amendments by the time of the signing of the Accession Treaty or at the latest by accession, but not before the provisional closure of a chapter. 
At this moment, it is still not entirely clear how the EU will approach all the mentioned constitutional issues during negotiations with Croatia, although indications exist based on the opened Chapters 17 and 32 . Regarding CNB independence (Chapter 17), the EU is asking Croatia, in the form of a closing benchmark, to align its legislative framework in order to ensure the full independence of the central bank and its full integration into the ESCB. The Constitution is not explicitly mentioned, but given the Commission's opinion expressed in the respective Screening Report, it can be implied as an element of discussions between Croatia and the EU. In Chapter 32, on the other hand, a more direct link has been made by the EU between the provisional closure of the Chapter and potential constitutional changes aimed at safeguarding the State Audit Office's independence (although a slightly different, alternative approach to this issue has also been offered as an option).

Although it seems that the Commission/EU has not (yet) taken a consistent position on the treatment of constitutional issues in negotiations with Croatia, it is possible to expect that the closing of negotiations could in some way be linked to constitutional changes. In view of the common understanding of the political and legal sensitivity of constitutional changes, and bearing in mind the legal formality of the closing benchmarks which need to be fulfilled by Croatia and then verified by the EU in order to close a chapter, it would be sensible for the EU, when deliberating on benchmarks, at least to make a distinction between the constitutional changes 'necessary' for legislative alignment and those which are not legally required but only advisable or prudent as additional guarantees, whereby in the latter case closing benchmarks would not be imposed, especially where particular elements of a constitutional nature could be resolved or interpreted in line with the acquis through laws or by courts.

II. Constitutional issues which have not been directly raised in negotiations with the EU, but which Croatia already needs to take into consideration at this stage of the accession process - eg general questions linked to EU accession, including the constitutional basis for accession

In contrast to the constitutional issues described above, where alignment with the acquis in preparation for EU membership is the main underlying factor for the potential constitutional change, there are a number of constitutional issues that Croatia has to decide on entirely autonomously. In principle, they are not directly related to legislative alignment with the acquis in specific negotiating chapters (although there are links with some of the chapters), but they arise from the very fact that Croatia is acceding to the EU, that is, to a very specific legal and political system 
in which it will have to function effectively and in accordance with the fundamental political and legal principles on which the EU is based. For the purpose of this paper, an overview is presented below of some of the main questions that might belong to this category:

- The constitutional basis for Croatia's EU membership - the question of how to accede to the EU: will one of the existing legal bases be used (Article 139, Article 141) or will a completely new legal basis be adopted?

Directly depending on this decision is the choice of a 'proper' legal basis for the potential organisation of a referendum on EU membership.

- A referendum on EU membership in Croatia - Article 86, Article 141 , or a new legal basis?

- The legal force, position and application of EU legislation in the Croatian legal system - Article 140 of the Constitution ${ }^{14}$ does not completely solve the question of the supremacy and direct effect of primary and secondary sources of EU law; the Constitution is silent on the issue of the legal force and effect of legal acts of international organisations to which Croatia can transfer powers derived from the Constitution through an international treaty based on Article 139, para 2;

- The question of regulating the relationship between Croatia's legislative, executive and judicial branches of power under EU membership conditions, enabling their participation in the EU while maintaining the efficiency of their work in Croatia (Articles 112 and $117^{15}$ ).

Especially pertinent here is the question of Parliament's role in monitoring the executive branch when representing Croatia at the EU level (in legislative and political decision-making in the Council and the European Council, including, for example, in the ESDP area). Experience with the National Committee in accession negotiations shows the increasing interest of the legislative branch in Croatia in monitoring the work of the executive branch (all EU Member States have different experiences with this issue and provide us with various examples and models).

- The status of EU nationals in Croatia in general, and ensuring their EU citizenship rights, including the right to vote in elections

\footnotetext{
14 Article 140 of the Croatian Constitution reads: 'International agreements concluded and ratified in accordance with the Constitution and made public, and which are in force, shall be part of the internal legal order of the Republic of Croatia and shall be above law in terms of legal effects. Their provisions may be changed or repealed only under conditions and in the way specified in them or in accordance with the general rules of international law'. Thus, the Constitution may still prevail over international, and potentially European, law.

15 Article 112 of the Constitution regulates the Government's executive powers, while Article 117 determines the judicial powers exercised by courts.
} 
for the European Parliament and to participate in local elections in Croatia (eg Articles 45 and 132 of the Constitution) - the latter issue is explained above under Chapter 23 - Judiciary and Fundamental Rights;

- The definition of sovereignty (Article 2); ${ }^{16}$

- The procedure for sending the armed forces over Croatian borders (Articles 7 and $82{ }^{17}$ ) - a question linked to the effectiveness of Croatia's participation in the CFSP/ESDP.

While sector-specific constitutional questions will be addressed in negotiations with the EU on individual chapters, the more fundamental constitutional issues are ultimately left to Croatia to decide on its own. This will be done after careful internal analysis at expert and political levels, which could lead to constitutional amendments that are assessed as necessary or useful. Hence, they will primarily be the subject of 'domestic' negotiations and exchanges of views within political, academic and expert circles deliberating on such constitutional changes with a view to reaching as wide a consensus as possible.

Since there were other contributions at the April 2007 Conference discussing in detail the issue of the constitutional legal basis for Croatia's accession to the EU and the related question of an EU referendum in Croatia, only a few general remarks in this respect are made here.

In the last enlargement round, some countries did not have the constitutional possibility and/or an adequate legal basis for EU accession or any delegation of powers to international institutions. Consequently, they had to create them. This is not the case in Croatia. On the contrary, judging by the existing views one could conclude that there is more than one possible legal basis in the Constitution for Croatia's accession to the EU. At first glance, this might seem like a simpler or more comfortable situation. However, it is hardly so, given the differences of opinions related to

\footnotetext{
16 Article 2 provides a rather traditional definition of sovereignty of the Republic of Croatia as 'inalienable, indivisible and non-transferable'. Although one could argue that this definition no longer corresponds to the changed perceptions and notions of sovereignty in international relations, and especially in the context of EU development, there are examples within the EU where the Member States, particularly those from Central and Eastern Europe, have preserved similar, and even stricter, definitions and safeguards on sovereignty for historical reasons (see in Albi, n 4). On the other hand, some Member States have, again for historical reasons, expressly envisaged limitations of their sovereignty (eg Italy). Others (like Slovenia) have foreseen transfers of the exercise of part of their sovereign rights to international organisations.

17 Under Article 7 of the Constitution, the armed forces of the Republic of Croatia may cross its borders or act over its borders only upon a prior decision of the Croatian Parliament passed by a two-thirds majority of all representatives in line with Article 82 (except in exercises within international defence organisations and in order to offer humanitarian aid, where the prior consent of Parliament is not necessary). This issue also has relevance for Croatia's NATO membership.
} 
which of these possibilities is the 'correct' one. Namely, the current constitutional provisions, due to their general nature and width on the one hand (Articles 86 and 139), or their specific nature on the other (Article 141 on association in state alliances), lead to different interpretations in legal and political circles in Croatia about which Constitution article is the appropriate legal basis for EU accession. Some even question whether either of them is the appropriate one. Moreover, the issue becomes even more sensitive when one takes into account that the choice between the existing constitutional bases for EU accession directly affects the manner in which the EU referendum could or should be organised in Croatia.

Having to choose between a couple of possibilities raises the question of how the EU, and Croatia's accession to it, should be understood and defined, so as to match this understanding with what is offered in the Constitution. Should Croatia's accession to the EU be treated as an association in an alliance with other states (Article 141 of the Constitution) or as accession to an international organisation through an international treaty, which grants the international organisation powers derived from the Constitution (Article 139)? ${ }^{18}$

(Un)fortunately, finding a common definition of the European Union is almost impossible, the numerous existing definitions being quite diverse and imprecise and not corresponding to traditional notions and divisions between states and international organisations. From being viewed as an 'ordinary' international organisation or an international organisation to which sovereign rights and powers are transferred, to being considered as a supranational organisation or integration sui generis resembling a federation, the EU is a real 'battlefield' of different ideas and ideals, often depending on the perceptions and attitudes of politicians and academics towards more or less integration or transfer of state sovereignty. From the perspective of accession negotiations - having in mind that EU accession is based on an international 'accession' treaty - it could be interpreted that a country is acceding to an international treaty organisation to which it transfers some of its constitutional powers. From the perspective of a Member State, the functioning of the EU does sometimes more resemble a state than an intergovernmental organisation. So, how is a future Member State to reconcile these two realities in its Constitution?

A significant number of both old and new EU Member States, when acceding to the EU and ratifying their Accession Treaties, have used their constitutional provisions concerning the ratification of international treaties or those enabling the transfer of powers to international institutions (or specifically to the EC/EU). Some of them did not have those provi-

18 There are even views that these two Articles should be applied cumulatively. 
sions beforehand, but had to amend their constitutions accordingly prior to EU accession. Croatia's Constitution already contains similar (general, not EU-specific) provisions in Articles 139 and 140 (Title VII International Relations), with para 2 of Article 139 requiring a large majority in the Croatian Parliament for the ratification of international treaties that grant the international organisation powers derived from the Constitution (potentially, for example, the EU Accession Treaty). ${ }^{19}$

On the other hand, some legal experts in Croatia hold the view that Croatia should accede (and hold a referendum) on the basis of Article 141 of the Constitution, interpreting thereby that by acceding to the EU Croatia is associating into an alliance with other states. ${ }^{20}$ Due to the lack of any precise definition of the term 'associating in alliance with other states' or its specific meaning used in Article 141, such wide interpretations of both Article 141 and the EU are perhaps theoretically possible, but as an important counterargument one should recall the very specific intention of this Article, which is particularly reflected in its paragraph 2 (prohibition to initiate any procedure for the association of the Republic of Croatia into alliances with other states if such association leads, or might lead, to a renewal of a South Slav state community or to any Balkan state form of any kind), as well as the time and rationale of its drafting (probably not intending to encompass accession to the European Community/European Union). ${ }^{21}$

A carefully chosen option and a widely accepted position on the appropriate legal basis for the possible organisation of a referendum in the context of EU accession are especially important if one bears in mind that, in comparison with the already quite demanding general provisions on referenda in Article 86, ${ }^{22}$ Article 141 stipulates an even larger majority of votes needed for a successful referendum, ${ }^{23}$ in addition to a complicated procedure which entails a previous decision of the Croatian Parlia-

\footnotetext{
19 According to Article 139, para 2 of the Constitution, for the ratification of international treaties that grant an international organisation powers derived from the Constitution, a two-thirds majority of votes of all representatives is needed, ie the same majority as required for constitutional amendments.

20 Article 2 additionally stipulates that the Republic of Croatia 'may conclude alliances with other states, retaining the sovereign right to decide by itself on the powers to be transferred and the right freely to withdraw from them'.

${ }^{21}$ An interesting comparison can be made with the Slovak Constitution, which contains a provision on entrance into 'state alliances' that has generally been interpreted as intended for closer relations with the Czech Republic, and not for EU accession.

22 At such referenda (eg on issues considered important for the independence, unity and existence of the Republic of Croatia), the decision shall be made by the majority of voters who have voted, provided that a majority of the total number of electors have taken part in the referendum.

23 Any decision concerning the association of the Republic of Croatia shall be made in a referendum by a majority vote of the total number of electors in the State.
} 
ment and a mandatory referendum (while a referendum under Article 86 is only optional, subject to a political decision).

Current political attitudes towards the potential holding of an EU membership referendum in Croatia are reflected in the Croatian Parliament's declarations and resolutions, ${ }^{24}$ which stipulate that Croatian citizens will decide on accession to the $\mathrm{EU}$ at a referendum that must be held before the signing of the Accession Treaty, ie following the conclusion of negotiations. The legal basis for such a referendum has not been specified, although it seems that a political decision to hold a referendum has already been made. ${ }^{25}$

Against this background, and not only to facilitate the successful holding of an EU referendum, some would argue that a comprehensive reform of the referenda system and the corresponding constitutional provisions is necessary. The reform could stretch from the general changes of thresholds and the voting majorities necessary for the passing of any referendum (both in Articles 86 and 141) or EU referenda in particular, to introducing consultative referenda or expressly limiting mandatory referenda only to certain topics and situations (leaving, for example, EU issues outside its scope). A combination of all these options is also possible.

In any event, a detailed analysis of the relevant constitutional and other legal provisions is needed in order either to establish the appropriate legal basis for EU accession and for carrying out a referendum on EU membership on the basis of existing constitutional provisions (such as Articles 86, 139 or 141), or to assess the possible need to adjust them to the specific nature of the EU and Croatia's accession to it.

Regarding the latter option, it is possible to consider, as a compromise solution, the introduction of a special 'EU clause' or an entire 'EU title' (as in France or Romania) into the Constitution. In addition to the questions of the legal bases for EU accession and a referendum, this clause or title could encompass other constitutional provisions concerning EU matters which it would be advisable to explicitly incorporate in the Croatian Constitution for the purposes of EU membership (eg Croatia's participation in European integration; the continuous transfer of executive, legislative and judicial powers to EU institutions, including in the area of concluding international agreements; recognition of the supremacy and direct effect of EU law; ratification/approval of further amendments to the EU treaties, etc). The drafting of such an 'EU clause/

${ }_{24}$ Eg Declaration of the Croatian Parliament on the fundamental principles of negotiations on full membership of the Republic of Croatia in the European Union (January 2005); Resolution of the Croatian Parliament on the strategic guidelines for negotiations between Croatia and the EU (October 2005).

25 There has been evident influence from the last enlargement round in which all new Member States, except Cyprus and Bulgaria, held referenda on EU membership. 
title' is a complex exercise since it needs to be adjusted to Croatia's overall constitutional framework and to be compatible with the EU's legal framework, which differs from national and international law. This would require further constitutional analysis in Croatia, whereby the Constitutions of individual Member States, which contain EU clauses and titles, could be analysed and used as an inspiration.

The experiences of both old and new Member States, as well as academic analyses, show that it is recommendable for a Member State to have its participation in the European integration process, ie EU development, reflected in the Constitution. This can particularly help to avoid the following situations:

- Ambiguities and different interpretations of constitutional provisions;

- Constitutional and other courts coming into conflict with the European Court of Justice regarding the application of the acquis, or discussions about which law has precedence - the national Constitution or EU law - in the case where the Constitution is in contradiction with the acquis;

- Repeated discussions on the EU's nature and the implications of EU membership, and ways to ratify further EU treaty amendments which occur from time to time since EU integration is a continuous process, implying the continuous transfer of powers to the EU.

\section{Possible further constitutional implications of EU membership following the entry into force of the latest EU treaty reform}

Croatian accession negotiations started in the midst of the EU Member States' attempts to carry out the most comprehensive constitutional/institutional/treaty reform of the EC/EU since its establishment, but which was put into question after two negative referenda and the consequent failure to ratify the Constitutional Treaty. For almost two years, this situation affected Croatia's accession negotiations, both politically, because the atmosphere within the EU was not conducive to further enlargement, and legally, since it was not clear on the basis of which Treaty/Treaties Croatia would accede to the EU. In 2007, the Member States finally managed to move the stalled treaty reform forward, by convening the Intergovernmental Conference and agreeing on the 'simpler' Reform Treaty, which 'only' amends and does not replace the existing founding Treaties. ${ }^{26}$ After its signature in Lisbon on 13 December 2007, the Lis-

\footnotetext{
26 Many authors and commentators argue that the 'simplified' Reform (Lisbon) Treaty ended up being too complex and not entirely coherent, ie the exact opposite of what was intended at the beginning of the reform process (Laeken Declaration). However, a similar line of criticism was, at the time, also used against the Constitutional Treaty by its opponents.
} 
bon Treaty ${ }^{27}$ is currently undergoing the ratification procedure in the EU Member States. ${ }^{28}$

Although substantially very similar and largely based on the text of the Constitutional Treaty, it could be said that the Lisbon Treaty was, from the constitutional point of view, slightly 'simplified'. Namely, it was precisely the perceived 'constitutional elements' from the Constitutional Treaty - ie those directly connected to the understanding of sovereignty and statehood - that were intensely disputed during the IGC by some Member States who wanted them out of the Treaty due to their alleged 'quasi-constitutional' symbolism. ${ }^{29}$ To avoid creating connotations with national Constitutions and/or to prevent the association of some Member States with the creation of a 'super-state', certain 'constitutional elements' were ultimately left out of the Lisbon Treaty (or altered if compared with the provisions of the signed Constitutional Treaty), eg: a) concerning the 'Constitutional Treaty' title, ${ }^{30}$ the word 'constitution' was not retained in the title of the new Treaty; b) instead of the Union Minister for Foreign Affairs, the old/new title of the High Representative of the Union for Foreign Affairs and Security Policy was accepted; c) the Charter of Fundamental Rights of the European Union was not incorporated into the Treaty, but was made legally binding (ie given the same legal value as the Treaties) 'only' through special reference to it in the Treaty; ${ }^{31}$ d) the flag and the anthem of the Union were no longer mentioned.

Croatia was not invited to participate (as observer) in the Intergovernmental Conference which prepared and adopted the Reform (Lisbon) Treaty. Like other candidate countries, it was only informed about the IGC deliberations and decisions. ${ }^{32}$ The opportunity to participate would have been a good catalyst for further internal deliberations and to raise awareness in Croatia about the real constitutional implications of EU membership, especially since the Lisbon Treaty contains some new (institutional)

\footnotetext{
27 Treaty of Lisbon amending the Treaty on European Union and the Treaty establishing the European Community [2007] OJ C 306.

28 The Treaty was supposed to enter into force on 1 January 2009, provided that all the instruments of ratification will have been deposited by that date. However, after the negative outcome of the Irish referendum held on 12 June 2008, this now seems unlikely. Instead, the Treaty will enter into force on the first day of the month following the deposit of the instrument of ratification by the last signatory State to take this step (Article 6 of the Lisbon Treaty).

29 Eg the position of the Czech government; Bulletin Quotidien Europe, No 9401, 5 April 2007, p 3.

30 Full title: Treaty establishing a Constitution for Europe.

31 Revised Article 6 TEU. Specific provisions have been agreed for Poland and the UK - see Protocol on the application of the Charter of Fundamental Rights of the European Union to Poland and to the United Kingdom.

32 In line with the European Council conclusions of June 2007.
} 
elements which might raise certain constitutional legal questions ${ }^{33}$ (eg the enhanced role of national parliaments in the EU decision-making and legislative procedures; possible simplified procedures for specific Treaty revisions; stronger references to the progressive establishment of a common defence; the explicit 'exit clause', ie the provision on the possibility of a 'negotiated' withdrawal from the EU). These new elements will have to be analysed in Croatia in order to assess their potential constitutional impact and to consider whether any constitutional modifications would be required in that respect.

Considering that Croatia had given its political support to the Constitutional Treaty and its principles, ${ }^{34}$ and that it expressed its commitment to respecting all the values, common policies and goals on which the EU is founded, ${ }^{35}$ Croatia should not have difficulties in accepting and acceding to the newly reformed Treaties. At the moment, however, the ratification ${ }^{36}$ and implementation ${ }^{37}$ of the Lisbon Treaty still remain a challenge, although one would hope in Croatia that the Treaty would enter into force at least by the time Croatia's accession negotiations are concluded and the Accession Treaty drafted. From both political and legal points of view, this would seem like a clearer and simpler scenario, although legally Croatia could accede to the EU also on the basis of the existing Treaties.

\section{Conclusion}

Based on the screening results, exchanged negotiating positions, and initial legal analyses at this stage of accession negotiations, a number of constitutional issues have been identified in relation to which Croatia will have to make more detailed constitutional analyses in order to examine the need to change the Constitution and the manner to do this in each particular case. In this exercise, it will be important to take into account the specific features of each individual question and decide on the most appropriate approach to potential constitutional changes, if and where a

\footnotetext{
33 As this was already the case in some Member States, eg Belgium, France, Ireland.

34 Through a separate statement at the signing ceremony in Rome on 29 October 2004.

35 Statement by the Croatian Parliament and the Government on joint actions in the process of negotiations on EU membership, 19 January 2005. <www.sabor.hr>.

36 More than 20 Member States have ratified the Treaty by now and the ratification process is continuing, despite the Irish 'no' vote. After initial consultations with the Irish government and analyses of the situation, the June European Council agreed to come back to the ratification issue at its October meeting in order to consider the way forward.

37 While awaiting ratifications, internal preparations to ensure the efficient application of the Lisbon Treaty novelties (as soon as it enters into force) have begun within the EU institutions. However, more open and detailed discussions on the actual implementation of the new Treaty can probably be expected only after a solution is found for the current impasse.
} 
change is assessed as necessary or useful. As shown above, the approach can vary according to the type of constitutional issue in question: the sector-specific issues related to legislative alignment in certain areas of the acquis can in principle be distinguished from the general constitutional issues related to finding the 'right formula' for Croatia's accession to and participation in the EU.

According to the initial analysis, it seems that there are no direct obstacles in the Croatian Constitution for Croatia's accession to the EU. However, certain adjustments of the constitutional framework will be needed, or, in some cases, as shown above, will at least be advisable:

1) to remove apparent limitations to achieving the full alignment and implementation of the acquis, which could, if unresolved, lead to a conflict of constitutional provisions with the acquis (eg the extradition of Croatian nationals on the basis of the European Arrest Warrant);

2) to ensure the most suitable constitutional legal basis and framework, not only for Croatia's accession but also for its effective functioning as a Member State within the EU.

The experiences of EU Member States - both old and new - can be valuable in this respect. However, as their examples show, there are no standard or best solutions - the 'most appropriate' solutions undeniably depend on a number of legal and political considerations and circumstances in each individual country and their respective legal systems. If there is perhaps one 'lesson learned', it is that it is desirable to have the EU accession and membership reflected in some way in the Constitution (eg through specific EU clauses or titles), which would, at the same time, also take into account further developments in the EU integration process.

In Croatia's case, during the process of negotiations, the Croatian Negotiating Team will gain full insight into the potential constitutional changes and issues where a constitutional change may be considered. Based on the experience thus far, some constitutional amendments will most likely even be demanded from the EU side. First, an expert and then a Government, Parliament or joint working group or commission would need to be formed to analyse, draft, and recommend possible modifications of the Constitution.

Whether, to what extent, and how Croatia ends up adjusting its constitutional legal framework for EU accession not only depends on legal considerations, but ultimately on a political decision of the Croatian Parliament, which, according to Article 143 of the Constitution, decides by a majority vote of all representatives whether or not to start proceedings for the amendment of the Constitution, after a proposal has been made by at least $1 / 5$ of parliamentarians, the President or the Govern- 
ment. The decision on actual amendments to the Constitution is made by the Parliament by a two-thirds majority vote of all its members.

Recently, some informal public discussions have taken place in Croatia on the potential wider reform of the Croatian Constitution, which could also entail constitutional adjustments linked to Croatia's EU accession. Expert and academic debates, like the one initiated at the April 2007 Conference, can be regarded as a valuable contribution to this process, laying down the foundations for further deliberations and the preparation of appropriate decisions by the responsible authorities and institutions in Croatia. 